\title{
A study of particulate matter concentration released during laser paint removal process on car coated substrate
}

\author{
*Mohammad Khairul Azhar Abdul Razab ${ }^{1,2}$, Mohamad Suhaimi Jaafar ${ }^{2}$, Azhar \\ Abdul Rahman ${ }^{2}$ \\ 1. Faculty of Earth Sciences, Universiti Malaysia Kelantan Jeli Campus, Locked Bag No. 100, 17600 Jeli, \\ Kelantan, Malaysia. \\ 2. School of Physics, Universiti Sains Malaysia Main Campus, 11800 Minden, Penang, Malaysia.
}

\begin{abstract}
Normalization mass (N) of particulate matter (PM) per one laser shot and $1.0 \mathrm{~cm}^{2}$ beam size released during the laser irradiation were measured on three different types of car coated substrate samples A, $B$ and $C$ by using DustTrak Aerosol Monitor 8520. The highest $N$ of $P M_{1.0}$ and $P M_{10.0}$ were $0.0485 \mathrm{mg} / \mathrm{shot}^{-\mathrm{cm}^{2}}$ and $0.0766 \mathrm{mg} / \mathrm{shot} / \mathrm{cm}^{2}$ for Sample A, $0.0890 \mathrm{mg} / \mathrm{shot} / \mathrm{cm}^{2}$ and $0.1728 \mathrm{mg} / \mathrm{shot}^{\mathrm{cm}} \mathrm{cm}^{2}$ for Sample B and 0.0530 $\mathrm{mg} / \mathrm{shot} / \mathrm{cm}^{2}$ and $0.0634 \mathrm{mg} / \mathrm{shot} / \mathrm{cm}^{2}$ for Sample C, respectively. Laser paint removal technique is considered safe than conventional chemical stripping process in term of health implications prevention and safety managements.
\end{abstract}

Keywords: Particulate matter, DustTrak 8520, Nd:YAG laser, Paint removal, Car coated substrate

\section{Introduction}

Chemical paint stripping process was intractable in preventing the health implications to the staff incharged due to continuous production of hazardous chemicals component as by-products sort of methylene chloride, phenolic compounds, activated acids, bases free from phenols and chromates and many more [1]. Conversely, health effects and environment pollution in laser paint removal is considered minimal in term of producing toxic, air contaminants, particulate matter, various metal particles and hazardous waste compare to conventional chemical techniques. However, the severe implications to these conditions is still exist [2,3]. This is due to tiny population of spherical and aggregates particulate matter (PM) ranged from nano to submicron particles was released from interaction between laser beam and target of painted layer during laser paint removal [4-6]. The emission rate of this hazardous substances is highly depending on the thickness and physical condition of the unwanted surface layer [7]. Clean Air Act (CAA) of USA declared PM is one of six major air pollutants and becomes the main factor for the establishment of National Ambient Air Quality Standards (NAAQS) by EPA [8].

PM could be either existed as solid particles or liquid droplets in a wide range of sizes [9, 10]. Aerosol PM with diameter less or equal to a nominal $10 \mu \mathrm{m}$ but greater than $2.5 \mu \mathrm{m}$ is known as $\mathrm{PM}_{10.0}$. $\mathrm{PM}_{10.0}$ accumulates in the upper respiratory tract to the lower respiratory system and can caused illness. In addition, aerosol PM with diameter less or equal to a nominal $1.0 \mu \mathrm{m}$ is known as $\mathrm{PM}_{1.0}[9,11]$.

Directly exposure to these aerosols of PM not only influenced the laser stripping process efficiency but more worst is increased the health risk of operators incharged $[4,5]$. Primary route of PM exposure is through inhalation and secondarily is through ingestion [9]. Acute and chronic exposure to aerosol PM leads to detrimental health effects $[9,10]$. Main portal entry for PM is lung, thus the interaction of PM with respiratory epithelium and alveolar macrophages will then induced the health risk to the pulmonary disease [8]. This condition becomes the main factors to aggravate lung disease sort of asthma and chronic obstructive pulmonary disease (COPD) which leads to cause lung cancer and cardiac problems $[9,12]$. Ultrafine PM is identified as highly toxic and poses the largest health risk due to its ability to migrate and deposit deep into the lung and risked the whole of respiratory system $[8,13]$.

The recommended values for annual and 24-hour mean concentrations are $20 \times 10^{-3} \mathrm{mg} / \mathrm{m}^{3}$ and $50 \times 10^{-}$ ${ }^{3} \mathrm{mg} / \mathrm{m}^{3}$ for $\mathrm{PM}_{10.0}$ and $10 \times 10^{-3} \mathrm{mg} / \mathrm{m}^{3}$ and $25 \times 10^{-3} \mathrm{mg} / \mathrm{m}^{3}$ for $\mathrm{PM}_{2.5}[14,15]$. There was no specific guideline for $\mathrm{PM}_{1.0}$ carried out from WHO, but the recommended mean concentration value for this particulate type should be less than $25 \times 10^{-3} \mathrm{mg} / \mathrm{m}^{3}$ for short term exposure. Nevertheless, the scientific recommendation for interim target values of PM from WHO was done in open air which based on the selected certain cities in the world, not in the workplace. In addition, the health risk due to hazardous PM is considered to highly dependent on the air exchange in the workplace, the size of the workplace, the way of spreading, distribution, compositions and types of the PM itself. There should have the threshold limit value (TLV) in the workplace as suggested by Kusch et al. (2003), which was $6 \mathrm{mg} / \mathrm{m}^{3}$ for totally independent of the chemical compositions of respirable dust [7]. But, there were no previous studies carried out regarding to the relationship between the size of workplace with the concentrations and distributions of PM released. 
To address this issue, a study to determine normalization mass $(N)$ of PM per one laser shot and 1.0 $\mathrm{cm}^{2}$ beam size released during the laser irradiation were done on three types of car coated substrate samples in a closed space. The experiment was carried out at Medical Physics Laboratory, School of Physics, Universiti Sains Malaysia, Penang.

\section{Experimental Set-Up}

Prior start the experiment, paint thickness for substrate samples of car models A, B and C were determined by using CEM DT-156 Paint Coating Thickness Gauge Tester F/NF Probe which ranged from 92 $134 \mu \mathrm{m}, 196-450 \mu \mathrm{m}, 219-283 \mu \mathrm{m}$, respectively and never repaints. A total 54 car coated substrate with consist of 18 samples by each type were irradiated by using Cynosure Cynergy Pulse Nd:YAG laser. Ten spotted laser irradiation was done on each substrate sample with $10 \mathrm{~J} / \mathrm{cm}^{2}$ increments of laser fluence $(F)$ by manipulating the pulse width (PW), repetition rate (RR) and beam size (BS) as listed in the Table 1 and Fig. 1.

\begin{tabular}{cccccc}
\multicolumn{6}{c}{ Table 1: Laser parameters considered for $3 \mathrm{~mm}$ and $5 \mathrm{~mm}$ BS with varies in $F$, PW and RR. } \\
\hline $\begin{array}{c}\text { Sample } \\
\text { number }\end{array}$ & $\begin{array}{c}\text { Number of } \\
\text { irradiation }\end{array}$ & $\begin{array}{c}\mathrm{BS} \\
(\mathrm{mm})\end{array}$ & $\begin{array}{c}F \\
\left(\mathrm{~J} / \mathrm{cm}^{2}\right)\end{array}$ & $\begin{array}{c}\mathrm{PW} \\
(\mathrm{ms})\end{array}$ & $\begin{array}{c}\mathrm{RR} \\
(\mathrm{Hz})\end{array}$ \\
\hline 1 & 10 & 3 & $210-300$ & 100 & 1.0 \\
2 & 10 & 3 & $210-300$ & 200 & 1.0 \\
3 & 10 & 3 & $210-300$ & 300 & 1.0 \\
4 & 10 & 3 & $210-300$ & 100 & 1.5 \\
5 & 10 & 3 & $210-300$ & 200 & 1.5 \\
6 & 10 & 3 & $210-300$ & 300 & 1.5 \\
7 & 10 & 3 & $210-300$ & 100 & 2.0 \\
8 & 10 & 3 & $210-300$ & 200 & 2.0 \\
9 & 10 & 3 & $210-300$ & 300 & 2.0 \\
10 & 10 & 5 & $150-240$ & 100 & 1.0 \\
11 & 10 & 5 & $150-240$ & 200 & 1.0 \\
12 & 10 & 5 & $150-240$ & 300 & 1.0 \\
13 & 10 & 5 & $150-240$ & 100 & 1.5 \\
14 & 10 & 5 & $150-240$ & 200 & 1.5 \\
15 & 10 & 5 & $150-240$ & 300 & 1.5 \\
16 & 10 & 5 & $60-150$ & 100 & 2.0 \\
17 & 10 & 5 & $60-150$ & 200 & 2.0 \\
18 & 10 & 5 & $60-150$ & 300 & 2.0 \\
\hline
\end{tabular}

Note: Maximum $F$ for $3 \mathrm{~mm} \mathrm{BS}$ is $300 \mathrm{~J} / \mathrm{cm}^{2}$ for all laser parameters. Meanwhile the maximum $F$ for $5 \mathrm{~mm}$ BS is $240 \mathrm{~J} / \mathrm{cm}^{2}$ set-up with RR 1.0 and $1.5 \mathrm{~Hz}$ whereas $150 \mathrm{~J} / \mathrm{cm}^{2}$ set-up with RR $2.0 \mathrm{~Hz}$.

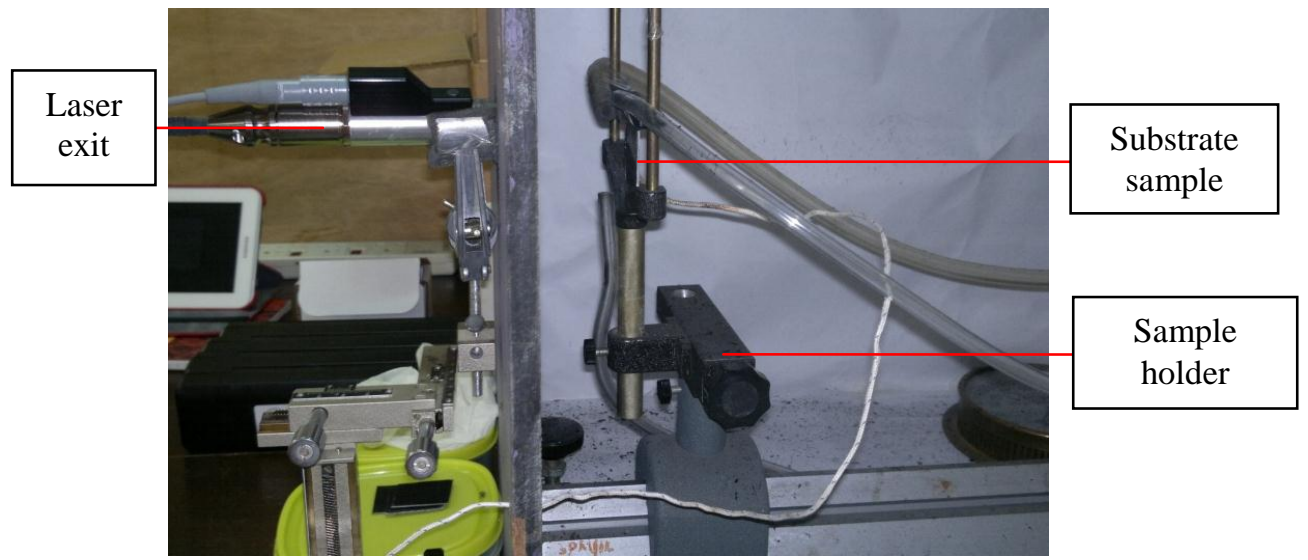

Figure 1: Experimental set-up for laser paint removal on the car coated substrate.

$\mathrm{PM}_{1.0}$ and $\mathrm{PM}_{10.0}$ were measured during laser paint removal process by using DustTrak Aerosol Monitor 8520. Both PM measurements were based on 10 minutes counting started from first irradiation on each certain substrate samples. For this study, some selection parameters were programmed to the DustTrak 8520 by using TrakPro software which were; (a) Time constant, (b) Logging interval and (c) Date and real-time clock.

Time constant is the average counting of PM within a certain period set-up. For this research, time constant was fixed at $1.0 \mathrm{~s}$ for all measurement means the PM detected actually was the average countings updated every second within a certain period. Meanwhile, logging interval was the time duration set-up to obtain a total of average PM countings. For all PM measurement, logging interval was set-up for 10 minutes; means a total of average countings (time constant) was obtained after 10 minutes measurements (logging 
interval). Date and real-time clock were synchronized to the current date and clock of the connected computer and updated automatically for countings identification. To ensure the validation data obtained, the device was calibrated to the standard requirement once equipped with the inlet nozzle by considering two calibration factors which were; (a) Re-zeroing, (b) Flow rate.

Re-zeroing process was done once changed the inlet nozzle in order to reset the internal circuit from kept track a total of aerosol quantity that had gone through the instrument. To re-zeroing the device, the zero filter was equipped to the sample inlet as shown in Fig. 2. By setting the DustTrak in survey mode, pressed and hold the calibrated button until the display counts to zero. Released the button immediately when the counts zero was reached and "calibrate zero" will be appeared on the display screen. Pressed the sample button and wait for $60 \mathrm{~s}$ countdown to determine the current calibration value. If the displayed value was between -0.001 to $+0.001 \mathrm{mg} / \mathrm{m}^{3}$, the device does not need any adjustment.

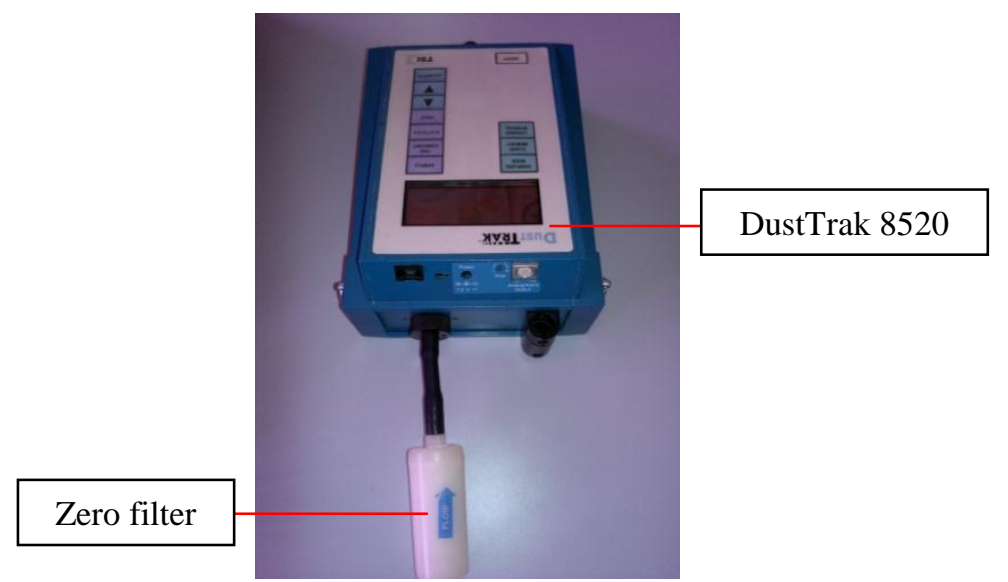

Figure 2: Re-zeroing of the DustTrak 8520 for new inlet nozzle installation.

Flow rate through the DustTrak monitor was set-up by connecting the flow meter tube to the sample inlet as shown in Fig. 3. By keeping the device in survey mode, the flow meter was adjusted by turning the flow adjustment screw located on the front top of the instrument. The factory setting for this calibration was 1.7 L/min.

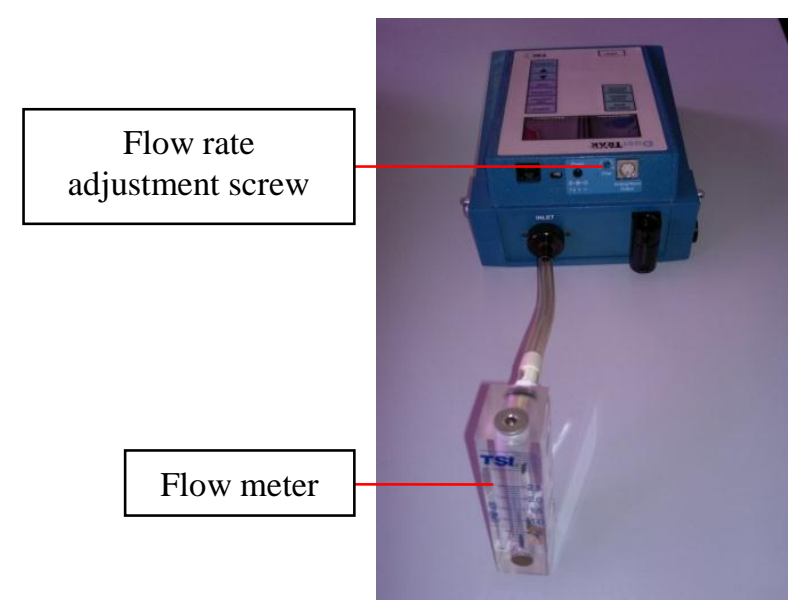

Figure 3: Flow rate of the DustTrak was set-up by using flow meter at $1.7 \mathrm{~L} / \mathrm{min}$.

Two DustTrak 8520 aerosol monitor was used together with the required inlet nozzle for specific size measurement of $\mathrm{PM}_{1.0}$ and $\mathrm{PM}_{10.0}$, respectively. $\mathrm{PM}_{1.0}$ and $\mathrm{PM}_{10.0}$ were measured in a close wood box with size $60.5 \mathrm{~cm}$ length, $40.5 \mathrm{~cm}$ wide and $40.5 \mathrm{~cm}$ height. The experimental set-up for this study was shown in Fig. 4 . 


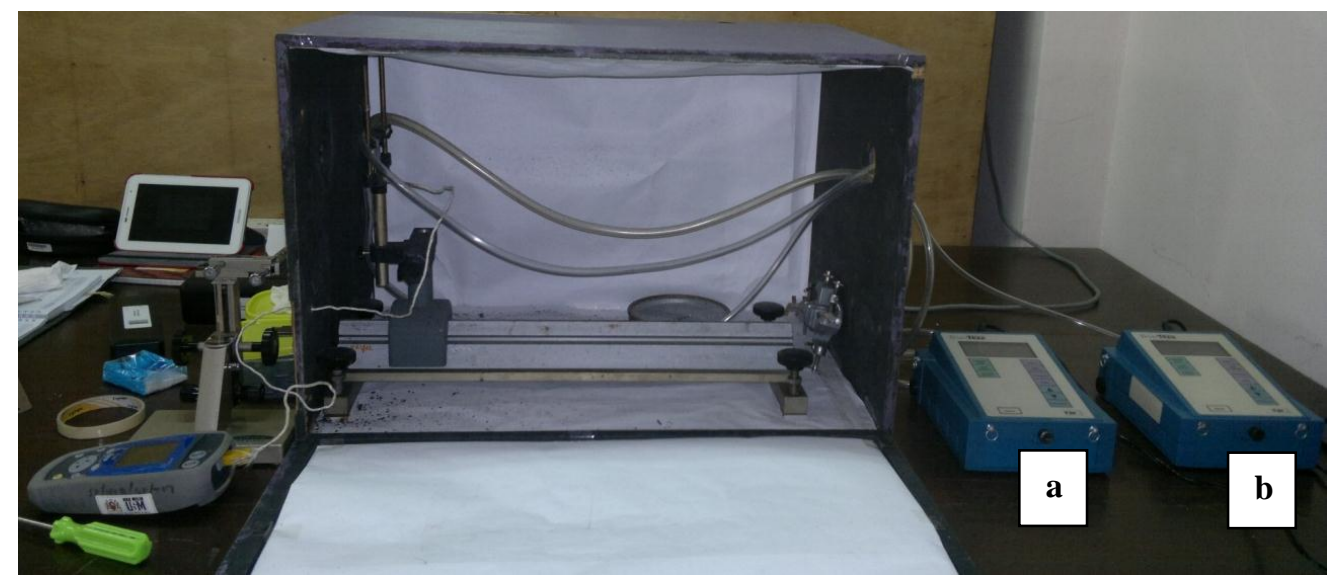

Figure 4: Experimental set-up of DustTrak 8520: a. DustTrak 8520 was set-up for $\mathrm{PM}_{10.0}$ and ready for measurement b. DustTrak 8520 was set-up for $\mathrm{PM}_{1.0}$ and ready for measurement.

\section{Results And Discussions}

Concentration of PM or aerosol by-products from laser paint removal process is depending on physical and chemical compositions of the ablated paint material and the laser parameters were used sort of $F$, PW, RR and BS $[5,7,16]$. The aerosols generated during the laser paint removal process were characterized in term of size distributions $\left(\mathrm{PM}_{1.0}\right.$ and $\left.\mathrm{PM}_{10.0}\right)$ and average of particle mass concentrations.

By assuming the spatial distributions of energy is homogenous for each shot on the painted material, it is possible to normalize the measurements with respect to the interaction of surface area [17]. Thus, each measurement of particle mass is related to one laser shot and $1.0 \mathrm{~cm}^{2}$ of ablated paint. (1) depicts the averaging method which was used to acquired the mass of particles, $N$ [5].

$$
N=d_{f} \times\left(\mathrm{C}_{\mathrm{Av}}-\mathrm{C}_{\text {noise }}\right) \times Q \times \Delta_{\mathrm{t}} /\left(n_{\text {shots }} \times A\right)
$$

Where $N$ is normalization mass of PM per one laser shot and $1.0 \mathrm{~cm}^{2}\left(\mathrm{mg} / \mathrm{shot} / \mathrm{cm}^{2}\right), d_{f}$ is the dilution factor, $\mathrm{C}_{\mathrm{Av}}$ $\left(\mathrm{mg} / \mathrm{m}^{3}\right)$ is the average concentration issued from the measurement device during $\Delta_{t}, \mathrm{C}_{\text {noise }}\left(\mathrm{mg} / \mathrm{m}^{3}\right)$ is the average concentration issued before laser shoots, $Q\left(\mathrm{~m}^{3} / \mathrm{min}\right)$ is the constant air flow rate of the device, $\Delta_{\mathrm{t}}(\mathrm{min})$ is the time interval for the PM accounted, $n_{\text {shots }}$ is the number of laser shoots within $\Delta_{\mathrm{t}}$ and $A\left(\mathrm{~cm}^{2}\right)$ is the irradiated crater area. For this analysis, the dilution factor $d_{f}$ is assumed to fix at value 1 due to no diluter was build in to the DustTrak 8520 .

PM concentration measurements results were classified into 3 main parts based on the 3 types of samples A, B and C as shown in Fig. 5, 6 and 7, respectively. Each part has 2 types of PM results, which were $\mathrm{PM}_{1.0}$ and $\mathrm{PM}_{10.0}$. The average of PM determined from the graph was applied in the (1) to obtain the $N$ for each substrate sample A, B and C as shown in Table 2. 


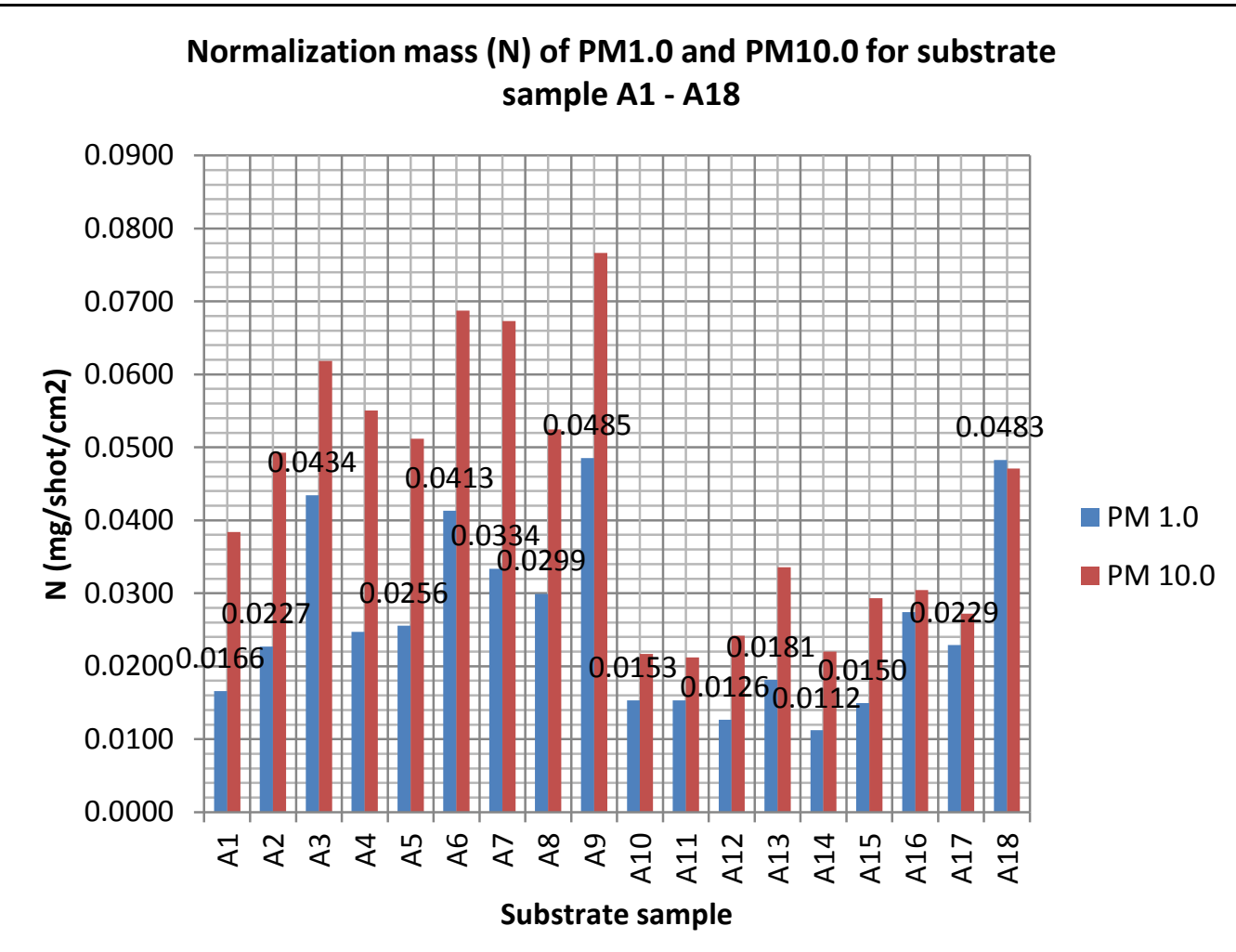

Figure 5: Normalization mass $(N)$ of $\mathrm{PM}_{1.0}$ and $\mathrm{PM}_{10.0}$ for substrate sample $\mathrm{A} 1$ - $\mathrm{A} 18$. The highest $N$ of $\mathrm{PM}_{1.0}$ and $\mathrm{PM}_{10.0}$ were $0.0485 \mathrm{mg} / \mathrm{shot} / \mathrm{cm}^{2}$ and $0.0766 \mathrm{mg} / \mathrm{shot} / \mathrm{cm}^{2}$ obtained from substrate sample A9.

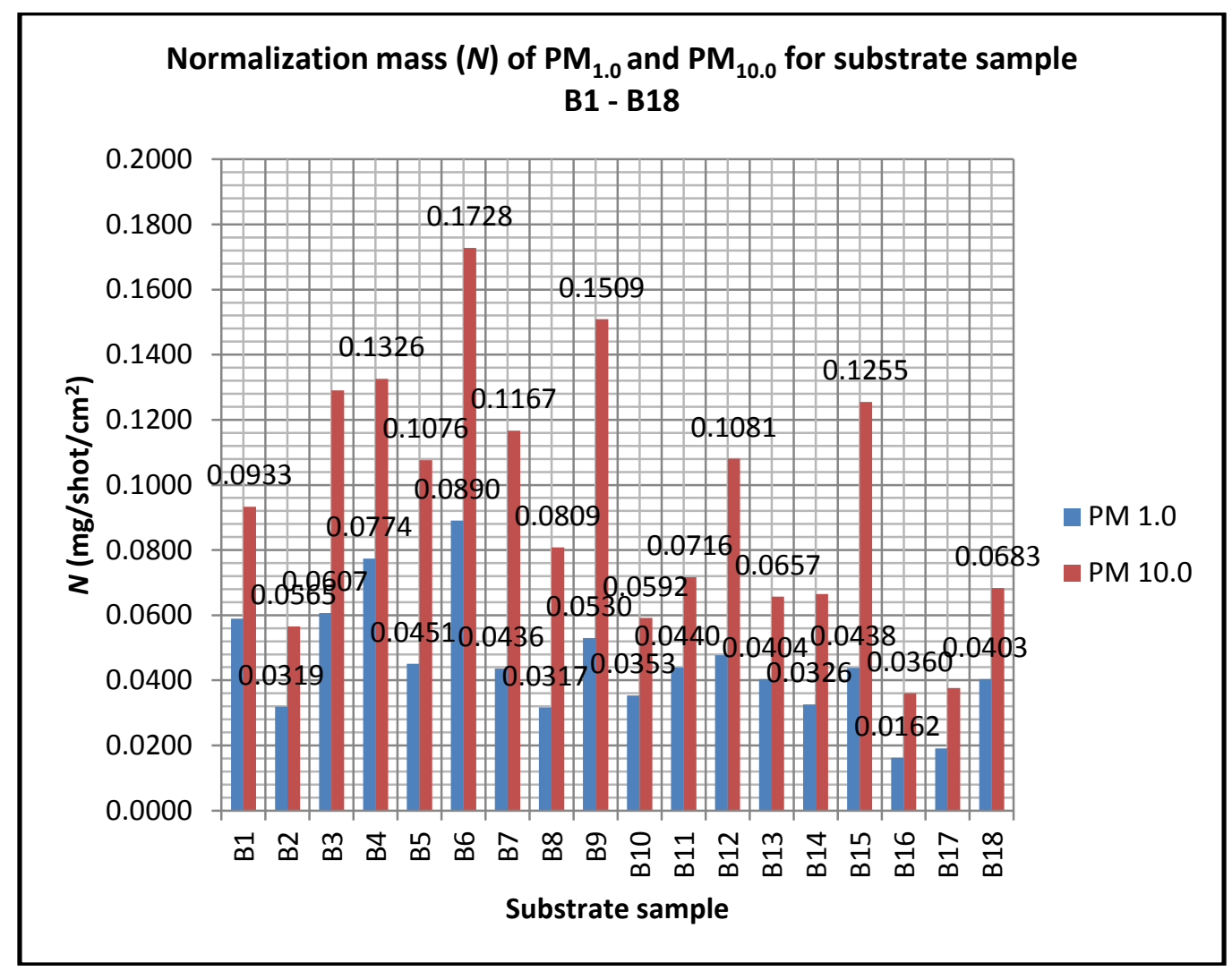

Figure 6: Normalization mass $(N)$ of $\mathrm{PM}_{1.0}$ and $\mathrm{PM}_{10.0}$ for substrate sample B1 - B18. The highest $N$ of $\mathrm{PM}_{1.0}$ and $\mathrm{PM}_{10.0}$ were $0.0890 \mathrm{mg} / \mathrm{shot} / \mathrm{cm}^{2}$ and $0.1728 \mathrm{mg} / \mathrm{shot} / \mathrm{cm}^{2}$ obtained from substrate sample B6. 


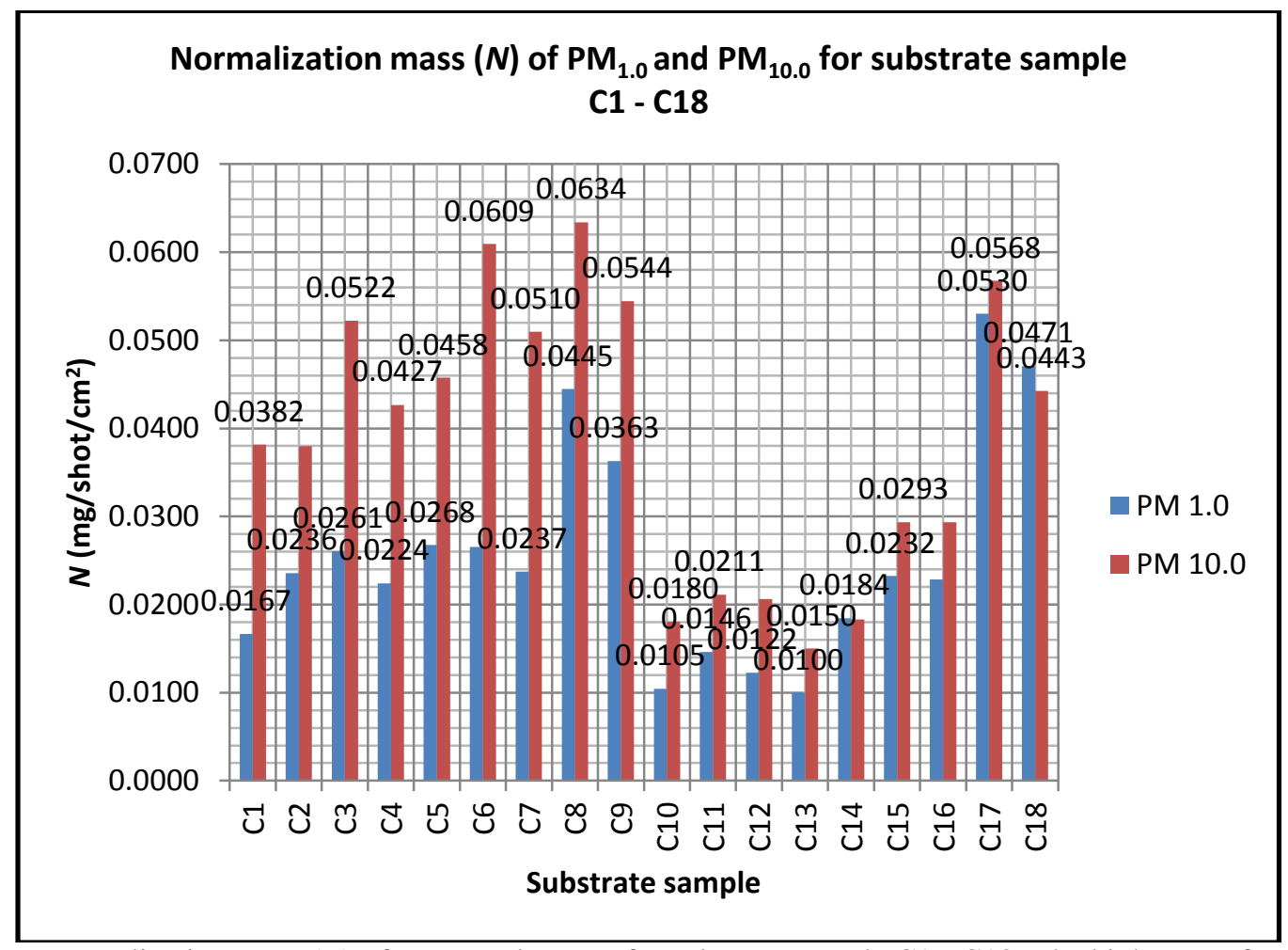

Figure 7: Normalization mass $(N)$ of $\mathrm{PM}_{1.0}$ and $\mathrm{PM}_{10.0}$ for substrate sample $\mathrm{C} 1-\mathrm{C} 18$. The highest $N$ of $\mathrm{PM} 1.0$ and $\mathrm{PM}_{10.0}$ were $0.0530 \mathrm{mg} / \mathrm{shot} / \mathrm{cm}^{2}$ and $0.0634 \mathrm{mg} / \mathrm{shot} / \mathrm{cm}^{2}$ obtained from substrate sample $\mathrm{C} 17$ and $\mathrm{C} 8$.

Table 2: Summarized of normalization mass $(N)$ of $\mathrm{PM}_{1.0}$ and $\mathrm{PM}_{10.0}$ per one laser shot and $1.0 \mathrm{~cm}^{2}$ for substrate sample A1 - A18, B1 - B18 and C1 - C18.

\begin{tabular}{|c|c|c|c|c|c|c|c|c|c|c|c|}
\hline Sample & $\begin{array}{c}\mathrm{RR} \\
(\mathrm{Hz})\end{array}$ & $\begin{array}{c}H \\
(\%) \\
\end{array}$ & $d_{f}$ & $Q\left(\mathrm{~m}^{3} / \mathrm{min}\right)$ & $n_{\text {shots }}$ & $\begin{array}{c}\Delta_{\mathrm{t}} \\
(\mathrm{min})\end{array}$ & $\begin{array}{c}A \\
\left(\mathrm{~cm}^{2}\right)\end{array}$ & $\begin{array}{c}C_{\text {noise }} \\
\left(\mathrm{mg} / \mathrm{m}^{3}\right)\end{array}$ & $\begin{array}{l}\text { Types } \\
\text { of PM }\end{array}$ & $\begin{array}{c}C_{\mathrm{av}} \\
\left(\mathrm{mg} / \mathrm{m}^{3}\right)\end{array}$ & $N\left(\mathrm{mg} / \mathrm{shot} / \mathrm{cm}^{2}\right)$ \\
\hline $\mathrm{A} 1$ & 1 & 73 & 1 & 0.0017 & 10 & 10 & 0.071 & 0.003 & $\begin{array}{l}\mathrm{PM}_{1.0} \\
\mathrm{PM}_{10.0}\end{array}$ & $\begin{array}{l}0.693 \\
1.598\end{array}$ & $\begin{array}{l}0.0166 \\
0.0384\end{array}$ \\
\hline A2 & 1 & 71 & 1 & 0.0017 & 10 & 10 & 0.071 & 0.005 & $\begin{array}{l}\mathrm{PM}_{1.0} \\
\mathrm{PM}_{10.0}\end{array}$ & $\begin{array}{l}0.948 \\
2.052\end{array}$ & $\begin{array}{l}0.0227 \\
0.0493\end{array}$ \\
\hline A3 & 1 & 71 & 1 & 0.0017 & 10 & 10 & 0.071 & 0.006 & $\begin{array}{l}\mathrm{PM}_{1.0} \\
\mathrm{PM}_{10.0}\end{array}$ & $\begin{array}{c}1.81 \\
2.575\end{array}$ & $\begin{array}{l}0.0434 \\
0.0619\end{array}$ \\
\hline A4 & 1.5 & 73 & 1 & 0.0017 & 10 & 10 & 0.071 & 0.004 & $\begin{array}{l}\mathrm{PM}_{1.0} \\
\mathrm{PM}_{10.0}\end{array}$ & $\begin{array}{l}1.031 \\
2.291\end{array}$ & $\begin{array}{l}0.0247 \\
0.0551\end{array}$ \\
\hline A5 & 1.5 & 71 & 1 & 0.0017 & 10 & 10 & 0.071 & 0.005 & $\begin{array}{l}\mathrm{PM}_{1.0} \\
\mathrm{PM}_{10.0}\end{array}$ & $\begin{array}{l}1.067 \\
2.131\end{array}$ & $\begin{array}{l}0.0256 \\
0.0512\end{array}$ \\
\hline A6 & 1.5 & 77 & 1 & 0.0017 & 10 & 10 & 0.071 & 0.001 & $\begin{array}{l}\mathrm{PM}_{1.0} \\
\mathrm{PM}_{10.0}\end{array}$ & $\begin{array}{l}1.717 \\
2.856\end{array}$ & $\begin{array}{l}0.0413 \\
0.0687\end{array}$ \\
\hline A7 & 2 & 74 & 1 & 0.0017 & 10 & 10 & 0.071 & 0.002 & $\begin{array}{l}\mathrm{PM}_{1.0} \\
\mathrm{PM}_{10.0}\end{array}$ & $\begin{array}{l}1.388 \\
2.798\end{array}$ & $\begin{array}{l}0.0334 \\
0.0673\end{array}$ \\
\hline A8 & 2 & 73 & 1 & 0.0017 & 10 & 10 & 0.071 & 0.003 & $\begin{array}{l}\mathrm{PM}_{1.0} \\
\mathrm{PM}_{10.0}\end{array}$ & $\begin{array}{l}1.246 \\
2.182\end{array}$ & $\begin{array}{l}0.0299 \\
0.0525\end{array}$ \\
\hline A9 & 2 & 74 & 1 & 0.0017 & 10 & 10 & 0.071 & 0.002 & $\begin{array}{l}\mathrm{PM}_{1.0} \\
\mathrm{PM}_{10.0}\end{array}$ & $\begin{array}{l}2.018 \\
3.185\end{array}$ & $\begin{array}{l}0.0485 \\
0.0766\end{array}$ \\
\hline A 10 & 1 & 73 & 1 & 0.0017 & 10 & 10 & 0.196 & 0.004 & $\begin{array}{l}\mathrm{PM}_{1.0} \\
\mathrm{PM}_{10.0}\end{array}$ & $\begin{array}{l}1.775 \\
2.505\end{array}$ & $\begin{array}{l}0.0153 \\
0.0217\end{array}$ \\
\hline A11 & 1 & 72 & 1 & 0.0017 & 10 & 10 & 0.196 & 0.004 & $\begin{array}{l}\mathrm{PM}_{1.0} \\
\mathrm{PM}_{10.0}\end{array}$ & $\begin{array}{l}1.775 \\
2.453\end{array}$ & $\begin{array}{l}0.0153 \\
0.0212\end{array}$ \\
\hline A12 & 1 & 71 & 1 & 0.0017 & 10 & 10 & 0.196 & 0.002 & $\begin{array}{l}\mathrm{PM}_{1.0} \\
\mathrm{PM}_{10.0}\end{array}$ & $\begin{array}{l}1.462 \\
2.794\end{array}$ & $\begin{array}{l}0.0126 \\
0.0242\end{array}$ \\
\hline A13 & 1.5 & 72 & 1 & 0.0017 & 10 & 10 & 0.196 & 0.005 & $\begin{array}{l}\mathrm{PM}_{1.0} \\
\mathrm{PM}_{10.0}\end{array}$ & $\begin{array}{l}2.098 \\
3.884\end{array}$ & $\begin{array}{l}0.0181 \\
0.0336\end{array}$ \\
\hline A14 & 1.5 & 72 & 1 & 0.0017 & 10 & 10 & 0.196 & 0.004 & $\begin{array}{l}\mathrm{PM}_{1.0} \\
\mathrm{PM}_{10.0}\end{array}$ & $\begin{array}{l}1.298 \\
2.545\end{array}$ & $\begin{array}{l}0.0112 \\
0.0220\end{array}$ \\
\hline A15 & 1.5 & 76 & 1 & 0.0017 & 10 & 10 & 0.196 & 0.003 & $\begin{array}{l}\mathrm{PM}_{1.0} \\
\mathrm{PM}_{10.0}\end{array}$ & $\begin{array}{l}1.731 \\
3.386\end{array}$ & $\begin{array}{l}0.0150 \\
0.0293\end{array}$ \\
\hline A16 & 2 & 74 & 1 & 0.0017 & 10 & 10 & 0.196 & 0.003 & $\begin{array}{l}\mathrm{PM}_{1.0} \\
\mathrm{PM}_{10.0}\end{array}$ & $\begin{array}{l}3.167 \\
3.516\end{array}$ & $\begin{array}{l}0.0274 \\
0.0304\end{array}$ \\
\hline A17 & 2 & 72 & 1 & 0.0017 & 10 & 10 & 0.196 & 0.005 & $\begin{array}{l}\mathrm{PM}_{1.0} \\
\mathrm{PM}_{10.0}\end{array}$ & $\begin{array}{c}2.65 \\
3.145\end{array}$ & $\begin{array}{l}0.0229 \\
0.0272\end{array}$ \\
\hline A18 & 2 & 74 & 1 & 0.0017 & 10 & 10 & 0.196 & 0.005 & $\mathrm{PM}_{1.0}$ & 5.578 & 0.0483 \\
\hline
\end{tabular}




\begin{tabular}{|c|c|c|c|c|c|c|c|c|c|c|c|}
\hline \multirow{3}{*}{ B1 } & \multirow{3}{*}{1} & \multirow{3}{*}{73} & \multirow{3}{*}{1} & \multirow{3}{*}{0.0017} & \multirow{3}{*}{10} & \multirow{3}{*}{10} & \multirow{3}{*}{0.071} & \multirow{3}{*}{0.003} & $\mathrm{PM}_{10.0}$ & 5.446 & 0.0471 \\
\hline & & & & & & & & & $\mathrm{PM}_{1.0}$ & 2.453 & 0.0590 \\
\hline & & & & & & & & & $\mathrm{PM}_{10.0}$ & 3.878 & 0.0933 \\
\hline \multirow[t]{2}{*}{ B2 } & 1 & \multirow{2}{*}{77} & \multirow[t]{2}{*}{1} & 0.0017 & 10 & 10 & 0.071 & 0.002 & $\mathrm{PM}_{1.0}$ & 1.328 & 0.0319 \\
\hline & & & & & & & & & $\mathrm{PM}_{10.0}$ & 2.35 & 0.0565 \\
\hline B3 & 1 & 76 & 1 & 0.0017 & 10 & 10 & 0.071 & 0.003 & $\mathrm{PM}_{1.0}$ & $\begin{array}{l}2.522 \\
5.364\end{array}$ & 0.0607 \\
\hline B4 & 1.5 & 72 & 1 & 0.0017 & 10 & 10 & 0.071 & 0.004 & $\mathrm{PM}_{1.0}$ & 3.217 & 0.0774 \\
\hline & & & & 0.0017 & & & 0.071 & 0.004 & $\mathrm{PM}_{10.0}$ & 5.512 & 0.1326 \\
\hline B5 & 1.5 & 73 & 1 & 0.0017 & 10 & 10 & 0.071 & 0.003 & $\mathrm{PM}_{1.0}$ & 1.875 & 0.0451 \\
\hline & & & & & & & & & $\begin{array}{c}\mathrm{PM}_{10.0} \\
\mathrm{PM}_{1.0}\end{array}$ & $\begin{array}{l}4.472 \\
3.701\end{array}$ & $\begin{array}{l}0.1076 \\
0.0890\end{array}$ \\
\hline B6 & 1.5 & 76 & 1 & 0.0017 & 10 & 10 & 0.071 & 0.004 & $\mathrm{PM}_{10.0}$ & 7.179 & 0.1728 \\
\hline B7 & 2 & 73 & 1 & 0.0017 & 10 & 10 & 0.071 & 0.002 & $\mathrm{PM}_{1.0}$ & 1.814 & 0.0436 \\
\hline & & & & & & & & & $\mathrm{PM}_{10.0}$ & 4.848 & 0.1167 \\
\hline B8 & 2 & 72 & 1 & 0.0017 & 10 & 10 & 0.071 & 0.002 & $\mathrm{PM}_{1.0}$ & $\begin{array}{l}1.318 \\
3.36\end{array}$ & $\begin{array}{l}0.0317 \\
0.0809\end{array}$ \\
\hline B9 & 2 & 76 & 1 & 00017 & 10 & 10 & 0.071 & 0003 & $\mathrm{PM}_{1.0}$ & 2.204 & 0.0530 \\
\hline & & & & 0.0017 & 10 & 10 & 0.071 & 0.003 & $\mathrm{PM}_{10.0}$ & 6.268 & 0.1509 \\
\hline B10 & 1 & 73 & 1 & 0.0017 & 10 & 10 & 0.196 & 0.005 & $\mathrm{PM}_{1.0}$ & 4.081 & 0.0353 \\
\hline & & & & & & & & & $\begin{array}{c}\mathbf{P M}_{10.0} \\
\mathrm{PM}_{1.0}\end{array}$ & $\begin{array}{c}6.839 \\
5.08\end{array}$ & $\begin{array}{l}0.0592 \\
0.0440\end{array}$ \\
\hline B11 & 1 & 76 & 1 & 0.0017 & 10 & 10 & 0.196 & 0.003 & $\mathrm{PM}_{10.0}$ & 8.276 & 0.0716 \\
\hline B12 & 1 & 75 & 1 & 0.0017 & 10 & 10 & 0.196 & 0.002 & $\mathrm{PM}_{1.0}$ & 5.517 & 0.0478 \\
\hline & & & & & & & & & $\mathrm{PM}_{10.0}$ & 12.48 & 0.1081 \\
\hline B13 & 1.5 & 72 & 1 & 0.0017 & 10 & 10 & 0.196 & 0.005 & $\mathrm{PM}_{1.0}$ & 4.671 & 0.0404 \\
\hline & & & & & & & & & $\begin{array}{l}\mathrm{PM}_{10.0} \\
\mathrm{PM}_{10}\end{array}$ & $\begin{array}{l}7.591 \\
3.774\end{array}$ & $\begin{array}{l}0.0657 \\
0.0326\end{array}$ \\
\hline B14 & 1.5 & 71 & 1 & 0.0017 & 10 & 10 & 0.196 & 0.006 & $\mathrm{PM}_{10.0}$ & 7.686 & 0.0665 \\
\hline B15 & 1.5 & 76 & 1 & 0.0017 & 10 & 10 & 0.196 & 0003 & $\mathrm{PM}_{1.0}$ & 5.065 & 0.0438 \\
\hline & & & & & & & 0.170 & 0.003 & $\mathrm{PM}_{10.0}$ & 14.49 & 0.1255 \\
\hline B16 & 2 & 73 & 1 & 0.0017 & 10 & 10 & 0.196 & 0.003 & $\mathrm{PM}_{1.0}$ & 1.87 & 0.0162 \\
\hline & & & & & & & & & $\begin{array}{c}\mathbf{P M}_{10.0} \\
\mathrm{PM}_{1.0}\end{array}$ & $\begin{array}{l}4.101 \\
2.207\end{array}$ & 0.0191 \\
\hline B17 & 2 & 72 & 1 & 0.0017 & 10 & 10 & 0.196 & 0.004 & $\mathrm{PM}_{10.0}$ & 4.349 & 0.0376 \\
\hline B18 & 2 & 70 & 1 & 0.0017 & 10 & 10 & 0.196 & 0.006 & $\mathrm{PM}_{1.0}$ & 4.664 & 0.0403 \\
\hline & & 10 & & 0.0017 & & 10 & 0.190 & 0.000 & $\mathrm{PM}_{10.0}$ & 7.898 & 0.0683 \\
\hline $\mathrm{C} 1$ & 1 & 70 & 1 & 0.0017 & 10 & 10 & 0.071 & 0.007 & $\mathrm{PM}_{1.0}$ & 0.699 & 0.0167 \\
\hline & & & & & & & & & $\mathrm{PM}_{10.0}$ & 1.592 & 0.0382 \\
\hline $\mathrm{C} 2$ & 1 & 71 & 1 & 0.0017 & 10 & 10 & 0.071 & 0.008 & $\mathrm{PM}_{1.0}$ & $\begin{array}{l}0.987 \\
1586\end{array}$ & $\begin{array}{l}0.0236 \\
0.2830\end{array}$ \\
\hline C3 & 1 & 77 & 1 & 0.0017 & 10 & 10 & 0.071 & 0.004 & $\mathrm{PM}_{1.0}$ & 1.086 & 0.0261 \\
\hline & & 11 & & 0.0017 & 10 & 10 & 0.071 & 0.004 & $\mathrm{PM}_{10.0}$ & 2.173 & 0.0522 \\
\hline $\mathrm{C} 4$ & 1.5 & 78 & 1 & 0.0017 & 10 & 10 & 0.071 & 0.003 & $\mathrm{PM}_{1.0}$ & 0.933 & 0.0224 \\
\hline & & & & & & & & & $\mathrm{PM}_{10.0}$ & 1.775 & 0.0427 \\
\hline C5 & 1.5 & 73 & 1 & 0.0017 & 10 & 10 & 0.071 & 0.006 & $\mathrm{PM}_{1.0}$ & 1.117 & 0.0268 \\
\hline C6 & 1.5 & 73 & 1 & 00017 & 10 & 10 & 0.071 & 0.006 & $\mathrm{PM}_{1.0}$ & $\begin{array}{l}1.900 \\
1.108\end{array}$ & 0.0265 \\
\hline co & & & & 0.0017 & 10 & 10 & 0.071 & 0.006 & $\mathrm{PM}_{10.0}$ & 2.536 & 0.0609 \\
\hline C7 & 2 & 76 & 1 & 0.0017 & 10 & 10 & 0.071 & 0.004 & $\mathrm{PM}_{1.0}$ & 0.989 & 0.0237 \\
\hline & & & & & & & & & $\mathrm{PM}_{10.0}$ & 2.12 & 0.0510 \\
\hline $\mathrm{C} 8$ & 2 & 78 & 1 & 0.0017 & 10 & 10 & 0.071 & 0.003 & $\mathrm{PM}_{1.0}$ & 1.85 & 0.0445 \\
\hline & & & & & & & & & $\begin{array}{c}\mathbf{P M}_{10.0} \\
\mathbf{P M}_{1.0}\end{array}$ & $\begin{array}{l}2.635 \\
1.512\end{array}$ & $\begin{array}{l}0.0634 \\
0.0363\end{array}$ \\
\hline C9 & 2 & 74 & 1 & 0.0017 & 10 & 10 & 0.071 & 0.006 & $\mathrm{PM}_{10.0}$ & 2.267 & 0.0544 \\
\hline C10 & 1 & 70 & 1 & 0.0017 & 10 & 10 & 0.196 & 0.002 & $\mathrm{PM}_{1.0}$ & 1.209 & 0.0105 \\
\hline & & & & & & & & & $\mathrm{PM}_{10.0}$ & $\begin{array}{l}2.086 \\
1.680\end{array}$ & 0.0180 \\
\hline C11 & 1 & 71 & 1 & 0.0017 & 10 & 10 & 0.196 & 0.003 & $\mathrm{PM}_{1.0}$ & $\begin{array}{l}1.689 \\
2.439\end{array}$ & $\begin{array}{l}0.0146 \\
0.0211\end{array}$ \\
\hline $\mathrm{C} 12$ & 1 & 75 & 1 & 00017 & 10 & 10 & 0196 & 0.005 & $\mathrm{PM}_{1.0}$ & 1.418 & 0.0122 \\
\hline & & & & & & & 0.196 & 0.005 & $\mathrm{PM}_{10.0}$ & 2.387 & 0.0206 \\
\hline $\mathrm{C} 13$ & 1.5 & 78 & 1 & 0.0017 & 10 & 10 & 0.196 & 0.003 & $\mathrm{PM}_{1.0}$ & 1.154 & 0.0100 \\
\hline & & & & & & & & & $\mathrm{PM}_{10.0}$ & 1.736 & 0.0150 \\
\hline C14 & 1.5 & 72 & 1 & 0.0017 & 10 & 10 & 0.196 & 0.005 & $\mathrm{PM}_{1.0}$ & 2.133 & 0.0184 \\
\hline & & & & & & & & & $\begin{array}{c}\mathrm{PM}_{10.0} \\
\mathrm{PM}_{10}\end{array}$ & $\begin{array}{l}2.119 \\
2.686\end{array}$ & $\begin{array}{l}0.0183 \\
0.0232\end{array}$ \\
\hline C15 & 1.5 & 73 & 1 & 0.0017 & 10 & 10 & 0.196 & 0.004 & $\mathrm{PM}_{10.0}$ & 3.39 & 0.0293 \\
\hline C16 & 2 & 75 & 1 & 00017 & 10 & 10 & 0196 & & $\mathrm{PM}_{1.0}$ & 2.641 & 0.0228 \\
\hline$C 10$ & 2 & 15 & 1 & 0.0017 & 10 & 10 & 0.196 & 0.004 & $\mathrm{PM}_{10.0}$ & 3.393 & 0.0293 \\
\hline C17 & 2 & 78 & 1 & 0.0017 & 10 & 10 & 0.196 & 0.002 & $\mathrm{PM}_{1.0}$ & 6.123 & 0.0530 \\
\hline & & & & & 10 & 10 & 0.190 & 0.002 & $\mathrm{PM}_{10.0}$ & 6.555 & 0.0568 \\
\hline $\mathrm{C} 18$ & 2 & 80 & 1 & 0.0017 & 10 & 10 & 0.196 & 0.001 & $\mathrm{PM}_{1.0}$ & 5.436 & 0.0471 \\
\hline
\end{tabular}




\subsection{Factors in producing the PM concentration in laser paint removal}

Bar graphs represented the concentrations of $\mathrm{PM}_{1.0}$ and $\mathrm{PM}_{10.0}$ produced for three types substrate sample A, B and C. The graphs were randomly distributed in term of RR and PW as shown in Figures 5, 6 and 7. This might be due to long PW 100, 200 and $300 \mathrm{~ms}$ with small range scale did not give significant impacts in term of irradiation duration. Indeed, lower ranged of RR 1.0, 1.5 and $2.0 \mathrm{~Hz}$ also did not give any clear effects as suggested in the literature, where the particles released should be increased as RR increased [18, 19].

However, the normalization mass of PM per one laser shot and $1.0 \mathrm{~cm}^{2}, N$ for both $\mathrm{PM}_{1.0}$ and $\mathrm{PM}_{10.0}$ were increased by using higher laser fluence energy ranged from $210-300 \mathrm{~J} / \mathrm{cm}^{2}$ compared to lower laser fluence energy ranged from $60-240 \mathrm{~J} / \mathrm{cm}^{2}$ as shown in the Tables 2 . This is because the higher laser fluence energy leads to generate more PM at the painted surface $[7,16]$. The results also revealed the application of 3 $\mathrm{mm}$ laser BS was produced higher $N$ concentrations compared to $5 \mathrm{~mm}$ laser BS. This is due to the higher laser fluence energy range was available at smaller BS as shown in Table 1 will be directly increased the concentration of laser beam [20].

In addition, emission rate of the PM was increased as the painted layer thickness increased, hence increased the hazardous substances released in workplace [7]. It was found that $\mathrm{PM}_{1.0}$ and $\mathrm{PM}_{10.0}$ concentrations released from sample B was highest due to the thickest of paint material.

Furthermore, surface roughness on the painted material was also influenced particle size distributions, where larger size of PM tends to be generated from the rough surface [16]. However, the surface roughness not considered as a main factors to influence the production of PM concentrations in this study due to the flat uniform surface of non-irradiated sample A, B and C. The results also revealed the air humidity did not give any significant effects to the PM released during laser paint removal. This is because, the humidity in air was dominant in influenced the production of PM for size greater than $20 \mu \mathrm{m}$ [7].

For this research, the highest $N$ of $\mathrm{PM}_{1.0}$ and $\mathrm{PM}_{10.0}$ were $0.0485 \mathrm{mg} / \mathrm{shot} / \mathrm{cm}^{2}$ and $0.0766 \mathrm{mg} / \mathrm{shot} / \mathrm{cm}^{2}$ for Sample A, $0.0890 \mathrm{mg} / \mathrm{shot} / \mathrm{cm}^{2}$ and $0.1728 \mathrm{mg} / \mathrm{shot} / \mathrm{cm}^{2}$ for Sample B and $0.0530 \mathrm{mg} / \mathrm{shot} / \mathrm{cm}^{2}$ and 0.0634 $\mathrm{mg} / \mathrm{shot} / \mathrm{cm}^{2}$ for Sample C, respectively.

\subsection{Effects to the paint removal efficiency process}

The productions of PM was effected the average coating removal efficiency $(\epsilon)$ if the particles released redeposited on the crater surface $[16,21]$. However, the plume produced during laser irradiation on painted material is considered as the main factors to effect the process efficiency [18, 19,22]. This is because some of the laser fluence energy was absorbed by the particle released in air, hence reduced the laser intensity to the next layers of the painted material [21]. Because of that, sample B which produced highest $N$ of $\mathrm{PM}_{1.0}$ and $\mathrm{PM}_{10.0}$ considered to produce lowest $\epsilon$. By the way, lower PM concentrations produced by sample A and C also in lined with their $\epsilon$ process, where lower $N$ productions of sample A and $\mathrm{C}$ give minor effects to the laser fluence energy to reach deep layers of painted material with a few reductions in laser intensity.

\section{Conclusion}

The highest $N$ of $\mathrm{PM}_{1.0}$ and $\mathrm{PM}_{10.0}$ measured in a close space were $0.0485 \mathrm{mg} / \mathrm{shot} / \mathrm{cm}^{2}$ and 0.0766 $\mathrm{mg} / \mathrm{shot} / \mathrm{cm}^{2}$ for Sample A, $0.0890 \mathrm{mg} / \mathrm{shot} / \mathrm{cm}^{2}$ and $0.1728 \mathrm{mg} / \mathrm{shot} / \mathrm{cm}^{2}$ for Sample B and $0.0530 \mathrm{mg} / \mathrm{shot} / \mathrm{cm}^{2}$ and $0.0634 \mathrm{mg} / \mathrm{shot} / \mathrm{cm}^{2}$ for Sample C, respectively. The lowest $C_{\mathrm{av}} \mathrm{PM}_{1.0}$ and $\mathrm{PM}_{10.0}$ concentrations detected during 10 minute laser irradiation with excluded the $C_{\text {noise }}$ were $0.693 \mathrm{mg} / \mathrm{m}^{3}$ and $1.586 \mathrm{mg} / \mathrm{m}^{3}$ as shown in Table 2. The results show both types of $\mathrm{PM}_{1.0}$ and $\mathrm{PM}_{10.0}$ concentration detected during the laser paint removal process were far exceed from the recommended values suggested by WHO. However, laser paint removal techniques was considered safe compared than chemical paint stripping technique if smooth air ventilation in workplace was properly set-up and inhalation to PM was greatly prevented by using protective mask.

\section{Acknowledgement}

The authors acknowledge the support of the Research University-Postgraduate Research Grant Scheme (RU-PRGS) [Grant Number 1001/PFIZIK/845008] awarded by Universiti Sains Malaysia. Great appreciation goes to Ministry of Higher Education and Universiti Malaysia Kelantan for providing a scholarship and financial assistance for this research project.

[1] Malavallon, O., Paint Removal Principles. AGARD, 1995.

[2] Wolf, K., Laser Strip: A Portable Hand-Held Laser Stripping Device for Reducing VOC, Toxic and Particulate Emission. 2009.

[3] Mongelli, G., Portable Handheld Laser Small Area Supplemental Coatings Removal System Final Report. 2005. p. 333.

[4] Dewalle, P., et al., Characterization of aerosols produced by laser-matter interaction during paint stripping experiments by laser. European Aerosol Conference, Salzburg, 2007.

[5] Dewalle, P., et al., Characterization of Aerosols Generated by Nanosecond Laser Ablation of an Acrylic Paint. Aerosol Science and Technology, 2010. 44(10): p. 902-915.

[6] Dudoitis, V., et al., Generation of metal nanoparticles by laser ablation. Lithuanian Journal of Physics, 2011. 51(3).

www.iosrjournals.org $47 \mid$ Page


[7] Kusch, H.-G., T. Heinze, and G. Wiedemann, Hazardous emissions and health risk during laser cleaning of natural stones. Journal of Cultural Heritage, 2003. 4: p. 38-44.

[8] Costa, D.L., Particulate matter Research Program. 2004

[9] McInnes, D.W., A Comparison of Gravimetric and Photometric Aerosol Samplers. 2009, DTIC Document.

[10] Kadiyala, A., Identification of factors affecting contaminant levels and determination of infiltration of ambient contaminants in public transport buses operating on biodiesel and ULSD fuels. 2008, University of Toledo.

[11] Brunekreef, B. and S.T. Holgate, Air pollution and health. The lancet, 2002. 360(9341): p. 1233-1242.

[12] Pope III, C.A., et al., Lung cancer, cardiopulmonary mortality, and long-term exposure to fine particulate air pollution. JAMA: the journal of the American Medical Association, 2002. 287(9): p. 1132-1141.

[13] Donaldson, K., et al., Ultrafine particles. Occupational and environmental medicine, 2001. 58(3): p. 211-216.

[14] WHO, WHO air quality guidelines for particulate matter, ozone, nitrogen dioxide and sulfur dioxide. 2006.

[15] Krzyzanowski, M. and A. Cohen, Update of WHO air quality guidelines. Air Quality, Atmosphere \& Health, 2008. 1(1): p. 7-13.

[16] Ostrowski, R., et al., Health risks caused by particulate emission during laser cleaning, in Lasers in the Conservation of Artworks. 2007, Springer. p. 623-630.

[17] Lee, D.-W. and M.-D. Cheng, Particle generation by ultraviolet-laser ablation during surface decontamination. Journal of the Air \& Waste Management Association, 2006. 56(11): p. 1591-1598.

[18] Madhukar, Y.K., et al., Effect of laser operating mode in paint removal with a fiber laser. Applied surface science, 2012

[19] Brygo, F., et al., Laser fluence, repetition rate and pulse duration effects on paint ablation. Applied surface science, 2006. 252(6): p. 2131-2138.

[20] Bäuerle, D., Laser processing and chemistry. 2011: Springer.

[21] Geleoc, M., E. Weisse, and F. Gensdarmes. Characterization of Laser-Generated Aerosols in Nd:YAG Ablation of Paint From Concrete Surfaces. in American Association for Aerosol Res. Annual Conference. 2004. Atlanta, Georgia, USA.

[22] Schmitz, T., et al., Characterization of aerosol plumes in nanosecond laser ablation of molecular solids at atmospheric pressure. Applied Physics B, 2010. 100(3): p. 521-533. 